\title{
Comparing South African annuIty options at RETIREMENT
}

\author{
Jeanie de Villiers-Strydom* \\ University of Stellenbosch \\ jeannie@sun.ac.za.
}

Received: October 2013

\author{
Niel Krige+ \\ University of Stellenbosch \\ jdkrige@sun.ac.za
}

Accepted: May 2014

\begin{abstract}
In this study various annuity strategies are compared for South African males who retired during the 30 years from 1960 to 1989. To this end, the present values of the monthly cash flows provided by 47 different annuity strategies are calculated and compared in order to ascertain which strategy would have provided the largest financial benefits. In contrast to previously held general beliefs, the calculations demonstrate that living annuity strategies are superior to composite annuity strategies, which in turn outperform switching annuity strategies, whereas life annuities yield the lowest return.
\end{abstract}

Keywords

Annuitisation, composite annuity strategies, life annuities, living annuities, switching annuity strategies.

*Ms J de Villiers-Strydom is a lecturer in the Department of Business Management, Stellenbosch University, South Africa.

\#Prof JD Krige is a professor in the Department of Business Management, Stellenbosch University, South Africa. 


\section{INTRODUCTION}

There is an array of options available to South African pensioners looking to purchase an income for life at retirement. Most individuals purchase either a life or a living annuity. This decision is often made without quantifying the potential benefits and risks of all the annuity options on offer (Goemans \& Ncube, 2008:i). In addition to investing in either life or living annuities, South African legislation allows retirees to follow alternative or mixed annuity strategies, which include composite and switching annuity strategies.

The purpose of this study is therefore to establish which of various annuity strategies would have been best to follow by South African males, aged 55, 60 and 65 respectively, who retired in each of the 30 years from 1960 to 1989 . To this end the present values of the monthly cash flows provided by 9 living annuity strategies ( 3 drawdown strategies combined with 3 asset allocations), 2 life annuity strategies (a level annuity and an annuity increasing by $5 \%$ each year), 18 composite annuity strategies ( 9 living annuity strategies combined with 2 life annuity strategies), and 18 switching annuity strategies (9 living annuity strategies switched to 2 life annuity strategies) were calculated in order to ascertain which strategy provided the largest financial benefits in present value terms.

For comparative purposes, this study constructed living annuities as if they had been available since 1960, even though they were only formally launched in the 1990s. Furthermore, withprofits annuities as well as inflation-linked life annuities were excluded from the study, due to their short history and relative lack of popularity.

As this study is based on historical data available up to December 2010 , a sub-period of 30 years was used (1960 to 1989) to ensure that the time period includes the expected date of decease of a male after retirement.

The paper is structured as follows. A literature review is presented in section 2, where both international and South African research in this field is explored. Section 3 describes the methodology employed to conduct the study, followed by a discussion of the results in Section 4 . Finally, in section 5 , a conclusion is drawn on the basis of the results.

\section{LITERATURE REVIEW}

A number of international studies have compared guaranteed life annuity strategies with phased withdrawal plans. The latter is comparable to South African living annuities. The more important studies are those by Kapur and Orszag (1999), Brown, Mitchell and Poterba (2001), Gerrard, Haberman and Vigna (2004) and Babbel and Merrill (2006). However, the most relevant studies are those by Dus, Maurer and Mitchell (2005) and Horneff, Maurer, Mitchell and Dus (2008). These two studies will be discussed in greater detail.

Dus et al. (2005) compared various phased withdrawal strategies to a real life annuity (i.e. an annuity indexed to inflation) benchmark under a risk-return framework for a male aged 65 , by doing a simulation on German data. The authors extended their comparison to the USA as well.

Their work extends prior research done in this field, by firstly measuring risk not only as the probability of a loss occurring, but by also taking into account the size of such a loss compared to a real life annuity benchmark. Secondly, they focused both on phased withdrawal plans with fixed benefits, as well as on phased withdrawal plans with variable benefit patterns. 
Considering all the phased withdrawal plans, there is no clearly dominant strategy, as all the strategies involve trade-offs between risk, benefits and bequests. Interestingly, the better strategies in terms of the expected present value of benefits resulted in very low equity exposure.

Finally, Dus et al. (2005) found that delaying annuitisation (i.e. switching from a phased withdrawal strategy to a real life annuity) until age 75 overall increases the value of the benefits and shrinks the shortfall. However, the potential for bequests decreases, indicating that the deferred annuitisation strategy is likely to be most appealing to retirees who wish to maximise payouts while alive. Purchasing the real life annuity at an even later age (85) promises more bequest potential at the cost of a higher shortfall during the annuitant's lifetime.

In an effort to compare a constant life annuity with phased withdrawals and a combination of the two, Horneff et al. (2008) simulated USA data under a utility framework with no bequest motive, thereby enabling them to also demonstrate the welfare implications of making annuitisation compulsory at a specific age. They considered the case for a female aged 65 .

The authors found that an initial blending strategy, where a life annuity is combined with a phased withdrawal plan, works well for retirees with moderate to high risk aversion, since the annuity portion of the investor's income is guaranteed. It can also enhance the benefits that investors receive by having exposure to the equity market. Individuals with low risk aversion will not invest in a constant life annuity. They found that a retiree with moderate aversion to risk is likely to invest approximately $60 \%$ of her wealth in annuities and $40 \%$ in a phased withdrawal plan.

They also concluded that less risk-averse retirees will probably wait longer until they switch to a life annuity, as higher interest rates are required to induce annuitisation among retirees, whereas very risk-averse individuals are usually willing to annuitise in a lower interest rate environment.

Finally, their results show that those retirees with moderate to high risk aversion benefit more from investing in a combination of a life annuity and a phased withdrawal plan initially at retirement, compared to a strategy where the retiree annuitises only at a later stage.

Two studies have been conducted in South Africa to compare annuity options at retirement. Goemans and Ncube (2008) analysed which of the main annuity types in South Africa were expected to provide the highest future lifetime income to a 60 -year-old male retiring with R500 000 on 31 December 2007 until age 90, by simulating 1000 scenarios.

They considered the risk and return characteristics of each annuity type. Risk refers to the probability of ruin, and is defined as the likelihood of not meeting specific income levels or benchmarks. Return refers to the expected present value of future income received.

Two guaranteed life annuities were considered, namely a level life annuity and a life annuity increasing by $5 \%$ every year, as well as one partially guaranteed life annuity, namely a with profits annuity. A 10 -year guaranteed term for the three life annuities applied. In addition, three living annuity drawdown strategies, with seven initial drawdown rates starting from the minimum of $2.5 \%$ through to the maximum of $17.5 \%$ of fund value in increments of $2.5 \%$, and five different asset allocations ranging from very aggressive to very conservative, were considered.

As expected, they found that in order to obtain the maximum expected income from a living annuity, the investor should follow an aggressive investment strategy and withdraw the maximum allowable income annually. Unfortunately, this option will result in a quickly 
decreasing cash flow pattern. Varying the drawdown rate over time helped in increasing the chance of obtaining the desired income pattern.

Moreover, the conclusion was made that if the retiree under investigation wishes to have a high probability of maintaining his initial income, the initial drawdown rate should not be more than $7.5 \%$. If growth of income is required, the initial drawdown rate should be reduced to $2.5 \%$ or $5 \%$, depending on risk preference. In terms of asset allocation it seems that a more conservative investment portfolio is optimal, with $25 \%$ of the underlying investment capital invested in equities.

The authors found that the two guaranteed life annuities, namely the level life annuity and the life annuity increasing by $5 \%$ every year, as well as the with-profits annuities, were far superior to the living annuity strategies, on a risk-value basis.

The main purpose of the study by Lodhia and Swanepoel (2012) was to evaluate the ability of a living annuity to provide a minimum real income for life, and to compare this to the income provided by an inflation-linked guaranteed life annuity.

They came to the conclusion that it is better to purchase a guaranteed annuity at age 65 as opposed to postponing it until a later age. Their research further suggests that it is unlikely for a retiree to have the capital required at, for example, 75 years of age to purchase the income he would have been receiving if he had bought the guaranteed annuity at retirement.

They found that a living annuity will need to deliver CPI $+5.5 \%$ for the average member in a living annuity who survives for 10 years after retirement in order to break even with a guaranteed annuity. Over the very long term, equities have returned investment growth of $\mathrm{CPI}+7 \%$, but with correspondingly high levels of volatility, which the authors argue the average retiree cannot afford to bear.

Lodhia and Swanepoel (2012) concluded that although a guaranteed annuity is better equipped to provide a real income for life, living annuities remain a suitable choice for the unhealthy and so-called impaired lives, who expect to die soon after retirement, as well as for very wealthy retirees with alternative sources of retirement income.

Both the studies by Goemans and Ncube (2008) and Lodhia and Swanepoel (2012) compare the present value of expected future income streams generated by various annuity options available to South African retirees. In contrast, this study focuses on what the experience of South Africans would have been who retired during the period 1960 to 1989, in terms of the various annuity options.

\section{DATA AND METHODOLOGY}

\subsection{Data}

In order to calculate the annuity payments provided by the various living, life, composite and switching annuity strategies, bond and equity market data was required, as well as life annuity rates. In addition, inflation data was required in order to discount annuity payments to a present value as at retirement. 


\subsubsection{Bond data}

Historical annual bond performance for the period 1960 to 1985 was obtained from the database compiled by Firer and McLeod (1999). The JSE-Actuaries Fixed Interest Performance Index was used from 1986 to 1997. Finally, The All Bond Index (ALBI) as developed by the Bond Exchange of South Africa and the Actuarial Society of South Africa was used from 1998 onwards.

\subsubsection{Equity data}

The JSE-Actuaries All Share Index was used to calculate annual historical performance of equities from 1960 to June 2002. The FTSE/JSE Africa Index Series replaced the JSE-Actuaries indices in June 2002 and were used from July 2002 onwards. Both price index and dividend yield data were obtained from the INet-Bridge database.

\subsubsection{Consumer Price Index (CPI) data}

The CPI as produced by Statistics South Africa (StatsSA) was used for the period under investigation, allowing for changes in the calculation of the CPI to bring South Africa in line with international best practice (StatsSA, 2009:1)

\subsubsection{Life annuity rates}

Life annuity rates were provided by Sanlam. Sanlam used the a(55) life mortality tables as published by Cambridge University Press in 1953 (Botha, Rossini, Geach, Goodall \& Du Preez, 2011:1056), as well as government bond rates with a term of 10 years and over, supplied by the South African Reserve Bank (SARB), to calculate life annuity rates. The life annuity rates provided by Sanlam very closely tracked their own published rates.

\subsection{Methodology}

As the purpose of this study is to establish which of various annuity strategies would have been best to follow by South African males, aged 55, 60 and 65 respectively, who retired in each of the 30 years from 1960 to 1989, the present values of the monthly cash flows provided by 9 living annuity strategies, 2 life annuity strategies, 18 composite annuity strategies and 18 switching annuity strategies - a total of 47 strategies - were calculated in order to ascertain which strategy provided the largest financial benefit in present value terms.

The present values of cash flows were calculated per Rl million invested for each strategy. The discount rate used to discount the cash flow of an annuity in month $\mathrm{n}$ was the geometric average of the inflation rates (the \% change in the CPI) through months one to $n$.

It was assumed that the male annuitants in the three age groups retired at the beginning of every year and that their life expectancy was that of the a(55) life mortality table as published by Cambridge University Press in 1953 (Botha et al., 2011:1056). According to this mortality table males aged 55, 60 and 65 respectively have life expectancies of 21, 18 and 14 years (rounded). The remaining capital at death was also discounted to a present value. 


\subsubsection{Living annuity strategies}

The present values of the monthly cash flows provided by three living annuity drawdown strategies were calculated, using existing equity and bond market index data with the following assumed asset allocations:

A. A conservative ( $25 \%$ equity; $75 \%$ bonds);

B. A moderate ( $50 \%$ equity; $50 \%$ bonds); and

C. An aggressive ( $75 \%$ equity; $25 \%$ bonds) risk profile.

Throughout the study the different asset allocations are referred to by these symbols $A, B$ and $C$.

The initial drawdown rates followed the recommendations of the Life Offices Association of South Africa's (LOA) Code on Living Annuities (LOA, 2008), and are given in TABLE 1 .

TABLE 1: Indicative life annuity rates

\begin{tabular}{lccccccc}
\hline \multicolumn{7}{c}{ Indicative life annuity rates } \\
\hline Age & 55 & 60 & 65 & 70 & 75 & 80 & 85 \\
Male & $5.5 \%$ & $6.2 \%$ & $7.3 \%$ & $8.7 \%$ & $10.7 \%$ & $13.5 \%$ & $17.5 \%$ \\
Female & $4.8 \%$ & $5.4 \%$ & $6.2 \%$ & $7.3 \%$ & $8.9 \%$ & $11.2 \%$ & $14.6 \%$ \\
\hline
\end{tabular}

Source: $\quad$ LA, 2008

It is recommended by the LOA that annuitants invested in living annuities should not withdraw more than the income available under life annuities (LOA, 2008). The initial drawdown rates of $5.5 \%, 6.2 \%$ and $7.3 \%$ for males aged 55,60 and 65 respectively are used in this study.

Three living annuity drawdown strategies were considered:

a) Maintaining the same drawdown rate throughout.

b) Adjusting the drawdown rate each year to increase the Rand amount of income by $5 \%$ per annum, but staying within the legal limits of between $2.5 \%$ and $17.5 \%$ of the underlying investment value.

c) Adjusting the drawdown rate each year to increase the Rand amount of income by the annual inflation rate, again remaining within the legal limits.

Throughout the study the different drawdown strategies are referred to by these symbols $a, b$ and $\mathrm{c}$.

Living annuity investments attract a number of costs. The following costs were taken into account in the calculations:

- An underlying base asset management fee including value-added tax (VAT) of $1.4 \%$ per annum on the equity portion of the portfolio, and $0.9 \%$ per annum on the bond portion of the portfolio;

- An annual adviser's fee of $0.57 \%$ including VAT; and

- A Linked Investment Service Provider (LISP) fee of $0.25 \%$ per annum of the portfolio. 
These rates were obtained by calculating the average fees for five of the largest general equity, and three of the largest bond unit trust funds.

The portfolios were rebalanced annually to maintain asset allocations.

Although living annuities have been marketed in South Africa only since the 1990s, it has been assumed for the purposes of this study that they have been in existence since 1960 .

For the living annuity strategies, the present values of cash flows for 810 combinations (three drawdown strategies combined with three asset allocations for three retirement ages over 30 years) were calculated.

\subsubsection{Life annuity strategies}

The second step of the study was to calculate the present values of the monthly cash flows provided by two life annuity strategies in order to establish which strategy provided the largest financial benefit in present value terms. The present values of the monthly cash flows provided by a single life annuity were calculated, with a 10 -year guaranteed term. Two strategies were considered: a level annuity and an annuity increasing by $5 \%$ every year. Initial commission of $1.71 \%$ including VAT was deducted from the consideration before the cash flows were calculated.

For the life annuity strategies, the present values of cash flows for 180 combinations (two life annuity strategies for three retirement ages over 30 years) were calculated.

\subsubsection{Composite annuity strategies}

The third step of the study was to calculate the present values of the monthly cash flows provided by composite annuity strategies in order to establish the financial benefits in present value terms of combining living annuity strategies with life annuity strategies on a 50/50 basis.

In this case there were 1620 combinations (nine living annuity strategies combined with two life annuity strategies for three retirement ages over 30 years).

\subsubsection{Switching annuity strategies}

The fourth step of the study was to calculate the present values of the monthly cash flows provided by switching annuity strategies in order to establish the financial benefits in present value terms of switching from a living annuity strategy to a life annuity strategy 10 years after retirement.

In this case there were 1620 combinations (nine living annuity strategies switched to two life annuity strategies for three retirement ages over 30 years).

\section{RESULTS}

For ease of reference the annuity strategies are expressed by an acronym of their parameters as best indicated by the following examples:

- Lif-5\%-60: a life annuity increasing by 5\% per annum and a retirement age of 60;

- Liv-A-b-55: a living annuity with asset allocation $A$, drawdown strategy $b$ and 
retirement age 55 ;

- $C[$ Liv-B-c-60-0\%]: a composite strategy between a living annuity with asset allocation $B$, drawdown strategy $c$, retirement age 60 and a level life annuity;

- S[Liv-C-a-65-5\%]: switching from a living annuity with asset allocation C, drawdown strategy a and retirement age 65 to a life annuity increasing by $5 \%$ per year.

Four key performance indicators (KPIs) were developed as measures by which annuity strategies could be evaluated. KPIs include average rank, best rank, number of victories (NOV), and percentile. The results for the KPIs for male retirees aged 55, 60 and 65 respectively are summarised in TABLES 2 to 4 . It should be noted that all options were sorted by average rank.

TABLE 2: All annuity strategies ranked by average rank for a male retiree aged 55

\begin{tabular}{|c|c|c|c|c|c|c|c|c|}
\hline \multicolumn{5}{|c|}{ Retirement age 55} & \multicolumn{4}{|c|}{$\%$ years above percentile } \\
\hline $\begin{array}{l}\text { Overall } \\
\text { rank }\end{array}$ & Option & $\begin{array}{c}\text { Average } \\
\text { rank }\end{array}$ & $\begin{array}{l}\text { Best } \\
\text { rank }\end{array}$ & NOV & $20 \%$ & $40 \%$ & $60 \%$ & $80 \%$ \\
\hline 1 & Liv-C-b-55 & 2.07 & 1 & 12 & $100 \%$ & $100 \%$ & $100 \%$ & $97 \%$ \\
\hline 2 & Liv-C-a-55 & 2.63 & 1 & 10 & $100 \%$ & $100 \%$ & $100 \%$ & $100 \%$ \\
\hline 3 & Liv-C-c-55 & 3.60 & 1 & 4 & $100 \%$ & $100 \%$ & $100 \%$ & $97 \%$ \\
\hline 4 & Liv-B-b-55 & 7.97 & 1 & 4 & $100 \%$ & $100 \%$ & $100 \%$ & $50 \%$ \\
\hline 5 & Liv-B-a-55 & 8.17 & 4 & 0 & $100 \%$ & $100 \%$ & $100 \%$ & $57 \%$ \\
\hline 6 & Liv-B-c-55 & 8.37 & 3 & 0 & $100 \%$ & $100 \%$ & $100 \%$ & $60 \%$ \\
\hline 7 & $C[$ Liv-C-b-55-0\%] & 9.57 & 5 & 0 & $100 \%$ & $100 \%$ & $100 \%$ & $57 \%$ \\
\hline 8 & $C[$ Liv-C-a-55-0\%] & 11.77 & 4 & 0 & $100 \%$ & $100 \%$ & $77 \%$ & $53 \%$ \\
\hline 9 & $C[$ Liv-C-b-55-5\%] & 12.23 & 7 & 0 & $100 \%$ & $100 \%$ & $97 \%$ & $10 \%$ \\
\hline 10 & $C[$ Liv-C-a-55-5\%] & 13.40 & 6 & 0 & $100 \%$ & $100 \%$ & $87 \%$ & $30 \%$ \\
\hline 11 & C[Liv-C-c-55-0\%] & 13.67 & 4 & 0 & $100 \%$ & $97 \%$ & $73 \%$ & $37 \%$ \\
\hline 12 & $S[$ Liv-C-b-55-0\%] & 15.77 & 4 & 0 & $97 \%$ & $87 \%$ & $67 \%$ & $33 \%$ \\
\hline 13 & C[Liv-C-c-55-5\%] & 15.80 & 7 & 0 & $100 \%$ & $100 \%$ & $77 \%$ & $10 \%$ \\
\hline 14 & Liv-A-c-55 & 16.10 & 4 & 0 & $100 \%$ & $87 \%$ & $57 \%$ & $43 \%$ \\
\hline 15 & $S[$ Liv-C-a-55-0\%] & 16.17 & 4 & 0 & $93 \%$ & $80 \%$ & $70 \%$ & $37 \%$ \\
\hline 16 & $S[$ Liv-C-c-55-0\%] & 17.13 & 4 & 0 & $93 \%$ & $83 \%$ & $67 \%$ & $30 \%$ \\
\hline 17 & C[Liv-B-b-55-0\%] & 18.23 & 12 & 0 & $100 \%$ & $100 \%$ & $47 \%$ & $0 \%$ \\
\hline 18 & $C[$ Liv-B-a-55-0\%] & 21.17 & 15 & 0 & $100 \%$ & $97 \%$ & $30 \%$ & $0 \%$ \\
\hline 19 & $S[$ Liv-C-a-55-5\%] & 21.43 & 7 & 0 & $90 \%$ & $77 \%$ & $43 \%$ & $20 \%$ \\
\hline 20 & Liv-A-b-55 & 21.57 & 2 & 0 & $100 \%$ & $53 \%$ & $33 \%$ & $30 \%$ \\
\hline 21 & $C[$ Liv-B-b-55-5\%] & 21.67 & 9 & 0 & $100 \%$ & $83 \%$ & $30 \%$ & $3 \%$ \\
\hline 22 & $S[$ Liv-C-b-55-5\%] & 22.03 & 8 & 0 & $87 \%$ & $77 \%$ & $50 \%$ & $7 \%$ \\
\hline
\end{tabular}




\begin{tabular}{|c|c|c|c|c|c|c|c|c|}
\hline \multicolumn{5}{|c|}{ Retirement age 55} & \multicolumn{4}{|c|}{$\%$ years above percentile } \\
\hline $\begin{array}{l}\text { Overall } \\
\text { rank }\end{array}$ & Option & $\begin{array}{c}\text { Average } \\
\text { rank }\end{array}$ & $\begin{array}{l}\text { Best } \\
\text { rank }\end{array}$ & NOV & $20 \%$ & $40 \%$ & $60 \%$ & $80 \%$ \\
\hline 23 & C[Liv-B-c-55-0\%] & 22.27 & 7 & 0 & $100 \%$ & $83 \%$ & $30 \%$ & $3 \%$ \\
\hline 24 & S[Liv-C-c-55-5\%] & 22.90 & 7 & 0 & $87 \%$ & $77 \%$ & $40 \%$ & $7 \%$ \\
\hline 25 & $C[$ Liv-B-a-55-5\%] & 23.97 & 14 & 0 & $100 \%$ & $80 \%$ & $13 \%$ & $0 \%$ \\
\hline 26 & C[Liv-B-C-55-5\%] & 24.73 & 13 & 0 & $100 \%$ & $67 \%$ & $27 \%$ & $0 \%$ \\
\hline 27 & Liv-A-a-55 & 25.50 & 5 & 0 & $83 \%$ & $47 \%$ & $30 \%$ & $27 \%$ \\
\hline 28 & $S[$ Liv-B-b-55-0\%] & 27.23 & 19 & 0 & $100 \%$ & $57 \%$ & $0 \%$ & $0 \%$ \\
\hline 29 & C[Liv-A-c-55-0\%] & 27.97 & 8 & 0 & $83 \%$ & $50 \%$ & $17 \%$ & $3 \%$ \\
\hline 30 & $S[$ Liv-B-c-55-0\%] & 28.40 & 20 & 0 & $97 \%$ & $47 \%$ & $0 \%$ & $0 \%$ \\
\hline 31 & $C[$ Liv-A-b-55-0\%] & 28.47 & 13 & 0 & $100 \%$ & $37 \%$ & $13 \%$ & $0 \%$ \\
\hline 32 & $\mathrm{~S}[$ Liv-B-a-55-0\%] & 28.63 & 19 & 0 & $90 \%$ & $50 \%$ & $0 \%$ & $0 \%$ \\
\hline 33 & C[Liv-A-c-55-5\%] & 30.60 & 14 & 0 & $77 \%$ & $40 \%$ & $7 \%$ & $0 \%$ \\
\hline 34 & $C[$ Liv-A-b-55-5\%] & 31.93 & 10 & 0 & $50 \%$ & $33 \%$ & $17 \%$ & $0 \%$ \\
\hline 35 & $C[$ Liv-A-a-55-0\%] & 32.63 & 20 & 0 & $97 \%$ & $27 \%$ & $0 \%$ & $0 \%$ \\
\hline 36 & $S[$ Liv-B-b-55-5\%] & 33.23 & 24 & 0 & $83 \%$ & $10 \%$ & $0 \%$ & $0 \%$ \\
\hline 37 & $S[$ Liv-B-a-55-5\%] & 33.80 & 22 & 0 & $73 \%$ & $20 \%$ & $0 \%$ & $0 \%$ \\
\hline 38 & $S[$ Liv-B-c-55-5\%] & 34.00 & 23 & 0 & $73 \%$ & $20 \%$ & $0 \%$ & $0 \%$ \\
\hline 39 & $C[$ Liv-A-a-55-5\%] & 35.67 & 15 & 0 & $40 \%$ & $20 \%$ & $3 \%$ & $0 \%$ \\
\hline 40 & $S[$ Liv-A-b-55-0\%] & 39.27 & 28 & 0 & $17 \%$ & $3 \%$ & $0 \%$ & $0 \%$ \\
\hline 41 & Lif- $0 \%-55$ & 39.47 & 19 & 0 & $37 \%$ & $13 \%$ & $0 \%$ & $0 \%$ \\
\hline 42 & $S[$ Liv-A-c-55-0\%] & 39.48 & 30 & 0 & $17 \%$ & $0 \%$ & $0 \%$ & $0 \%$ \\
\hline 43 & $S[$ Liv-A-a-55-0\%] & 41.47 & 29 & 0 & $13 \%$ & $0 \%$ & $0 \%$ & $0 \%$ \\
\hline 44 & $S[$ Liv-A-c-55-5\%] & 43.23 & 35 & 0 & $7 \%$ & $0 \%$ & $0 \%$ & $0 \%$ \\
\hline 45 & S[Liv-A-b-55-5\%] & 43.27 & 32 & 0 & $3 \%$ & $0 \%$ & $0 \%$ & $0 \%$ \\
\hline 46 & $S[$ Liv-A-a-55-5\%] & 44.40 & 33 & 0 & $7 \%$ & $0 \%$ & $0 \%$ & $0 \%$ \\
\hline 47 & Lif- $5 \%-55$ & 45.00 & 32 & 0 & $7 \%$ & $0 \%$ & $0 \%$ & $0 \%$ \\
\hline
\end{tabular}

Source: Authors, 2012 
De Villiers-Strydom \& Krige

TABLE 3: All annuity strategies ranked by average rank for a male retiree aged 60

\begin{tabular}{|c|c|c|c|c|c|c|c|c|}
\hline \multicolumn{5}{|c|}{ Retirement age 60} & \multicolumn{4}{|c|}{$\%$ years above percentile } \\
\hline $\begin{array}{l}\text { Overall } \\
\text { rank }\end{array}$ & Option & $\begin{array}{c}\text { Average } \\
\text { rank }\end{array}$ & $\begin{array}{l}\text { Best } \\
\text { rank }\end{array}$ & NOV & $20 \%$ & $40 \%$ & $60 \%$ & $80 \%$ \\
\hline 1 & Liv-C-b-60 & 2.53 & 1 & 14 & $100 \%$ & $100 \%$ & $100 \%$ & $97 \%$ \\
\hline 2 & Liv-C-a-60 & 2.63 & 1 & 12 & $100 \%$ & $100 \%$ & $100 \%$ & $100 \%$ \\
\hline 3 & Liv-C-c-60 & 3.63 & 1 & 1 & $100 \%$ & $100 \%$ & $97 \%$ & $97 \%$ \\
\hline 4 & Liv-B-c-60 & 7.23 & 2 & 0 & $100 \%$ & $100 \%$ & $100 \%$ & $70 \%$ \\
\hline 5 & Liv-B-b-60 & 7.70 & 1 & 1 & $100 \%$ & $100 \%$ & $100 \%$ & $57 \%$ \\
\hline 6 & Liv-B-a-60 & 8.30 & 4 & 0 & $100 \%$ & $100 \%$ & $97 \%$ & $70 \%$ \\
\hline 7 & $C[$ Liv-C-b-60-0\%] & 9.87 & 4 & 0 & $100 \%$ & $100 \%$ & $90 \%$ & $67 \%$ \\
\hline 8 & $C[$ Liv- $-\mathrm{a}-60-0 \%]$ & 11.40 & 4 & 0 & $100 \%$ & $97 \%$ & $83 \%$ & $57 \%$ \\
\hline 9 & C[Liv-C-c-60-0\%] & 12.73 & 5 & 0 & $100 \%$ & $93 \%$ & $83 \%$ & $40 \%$ \\
\hline 10 & $C[$ Liv-C-b-60-5\%] & 13.10 & 6 & 0 & $100 \%$ & $100 \%$ & $90 \%$ & $10 \%$ \\
\hline 11 & $C[$ Liv-C-a-60-5\%] & 13.67 & 6 & 0 & $100 \%$ & $97 \%$ & $87 \%$ & $30 \%$ \\
\hline 12 & Liv-A-c-60 & 14.07 & 4 & 0 & $100 \%$ & $93 \%$ & $63 \%$ & $37 \%$ \\
\hline 13 & C[Liv-C-c-60-5\%] & 16.10 & 9 & 0 & $100 \%$ & $100 \%$ & $77 \%$ & $7 \%$ \\
\hline 14 & $S[$ Liv-C-a-60-0\%] & 16.93 & 4 & 0 & $93 \%$ & $80 \%$ & $70 \%$ & $27 \%$ \\
\hline 15 & $S[$ Liv-C-b-60-0\%] & 16.97 & 5 & 0 & $97 \%$ & $87 \%$ & $67 \%$ & $27 \%$ \\
\hline 16 & $S[$ Liv-C-c-60-0\%] & 17.03 & 4 & 0 & $93 \%$ & $83 \%$ & $67 \%$ & $20 \%$ \\
\hline 17 & $C[$ Liv-B-b-60-0\%] & 18.70 & 11 & 0 & $100 \%$ & $100 \%$ & $40 \%$ & $0 \%$ \\
\hline 18 & C[Liv-B-C-60-0\%] & 20.33 & 6 & 0 & $100 \%$ & $97 \%$ & $30 \%$ & $7 \%$ \\
\hline 19 & $C[$ Liv-B-a-60-0\%] & 20.67 & 14 & 0 & $100 \%$ & $97 \%$ & $33 \%$ & $0 \%$ \\
\hline 20 & Liv-A-b-60 & 21.80 & 1 & 2 & $100 \%$ & $57 \%$ & $30 \%$ & $27 \%$ \\
\hline 21 & $C[$ Liv-B-b-60-5\%] & 22.13 & 11 & 0 & $100 \%$ & $93 \%$ & $20 \%$ & $0 \%$ \\
\hline 22 & $S[$ Liv-C-a-60-5\%] & 22.47 & 7 & 0 & $87 \%$ & $73 \%$ & $47 \%$ & $13 \%$ \\
\hline 23 & $S[$ Liv-C-c-60-5\%] & 23.20 & 8 & 0 & $90 \%$ & $80 \%$ & $40 \%$ & $3 \%$ \\
\hline 24 & $C[$ Liv-B-c-60-5\%] & 23.53 & 10 & 0 & $100 \%$ & $80 \%$ & $23 \%$ & $0 \%$ \\
\hline 25 & $S[$ Liv-C-b-60-5\%] & 23.73 & 9 & 0 & $87 \%$ & $77 \%$ & $37 \%$ & $3 \%$ \\
\hline 26 & $C[$ Liv-B-a-60-5\%] & 24.13 & 15 & 0 & $100 \%$ & $77 \%$ & $13 \%$ & $0 \%$ \\
\hline 27 & C[Liv-A-c-60-0\%] & 25.80 & 8 & 0 & $93 \%$ & $63 \%$ & $23 \%$ & $7 \%$ \\
\hline 28 & Liv-A-a-60 & 25.93 & 2 & 0 & $87 \%$ & $37 \%$ & $30 \%$ & $23 \%$ \\
\hline 29 & $S[$ Liv-B-c-60-0\%] & 27.80 & 19 & 0 & $100 \%$ & $47 \%$ & $0 \%$ & $0 \%$ \\
\hline 30 & $C[$ Liv-A-b-60-0\%] & 28.13 & 7 & 0 & $100 \%$ & $43 \%$ & $13 \%$ & $3 \%$ \\
\hline 31 & $S[$ Liv-B-b-60-0\%] & 28.53 & 16 & 0 & $100 \%$ & $50 \%$ & $3 \%$ & $0 \%$ \\
\hline
\end{tabular}

442 Journal of Economic and Financial Sciences /JEF / July 2014 7(2), pp. 433-450 


\begin{tabular}{|c|c|c|c|c|c|c|c|c|}
\hline \multicolumn{5}{|c|}{ Retirement age 60} & \multicolumn{4}{|c|}{$\%$ years above percentile } \\
\hline $\begin{array}{l}\text { Overall } \\
\text { rank }\end{array}$ & Option & $\begin{array}{c}\text { Average } \\
\text { rank }\end{array}$ & $\begin{array}{l}\text { Best } \\
\text { rank }\end{array}$ & NOV & $20 \%$ & $40 \%$ & $60 \%$ & $80 \%$ \\
\hline 32 & $C[$ Liv-A-c-60-5\%] & 29.00 & 12 & 0 & $83 \%$ & $43 \%$ & $17 \%$ & $0 \%$ \\
\hline 33 & $S[$ Liv-B-a-60-0\%] & 30.07 & 19 & 0 & $87 \%$ & $37 \%$ & $0 \%$ & $0 \%$ \\
\hline 34 & $C[$ Liv-A-a-60-0\%] & 31.73 & 11 & 0 & $97 \%$ & $27 \%$ & $7 \%$ & $0 \%$ \\
\hline 35 & $C[$ Liv-A-b-60-5\%] & 31.87 & 6 & 0 & $60 \%$ & $23 \%$ & $17 \%$ & $3 \%$ \\
\hline 36 & $S[$ Liv-B-c-60-5\%] & 33.63 & 23 & 0 & $73 \%$ & $17 \%$ & $0 \%$ & $0 \%$ \\
\hline 37 & $S[$ Liv-B-b-60-5\%] & 34.73 & 24 & 0 & $67 \%$ & $7 \%$ & $0 \%$ & $0 \%$ \\
\hline 38 & $C[$ Liv-A-a-60-5\%] & 35.40 & 10 & 0 & $40 \%$ & $17 \%$ & $7 \%$ & $0 \%$ \\
\hline 39 & $S[$ Liv-B-a-60-5\%] & 35.43 & 22 & 0 & $57 \%$ & $13 \%$ & $0 \%$ & $0 \%$ \\
\hline 40 & Lif- $0 \%-60$ & 38.43 & 19 & 0 & $40 \%$ & $13 \%$ & $0 \%$ & $0 \%$ \\
\hline 41 & $\mathrm{~S}[$ Liv-A-c-60-0\%] & 39.20 & 30 & 0 & $23 \%$ & $0 \%$ & $0 \%$ & $0 \%$ \\
\hline 42 & $\mathrm{~S}[$ Liv-A-b-60-0\%] & 40.13 & 28 & 0 & $13 \%$ & $3 \%$ & $0 \%$ & $0 \%$ \\
\hline 43 & $S[$ Liv-A-a-60-0\%] & 42.37 & 29 & 0 & $10 \%$ & $0 \%$ & $0 \%$ & $0 \%$ \\
\hline 44 & $S[$ Liv-A-c-60-5\%] & 42.60 & 35 & 0 & $7 \%$ & $0 \%$ & $0 \%$ & $0 \%$ \\
\hline 45 & Lif- $5 \%-60$ & 43.47 & 29 & 0 & $10 \%$ & $0 \%$ & $0 \%$ & $0 \%$ \\
\hline 46 & $S[$ Liv-A-b-60-5\%] & 43.97 & 36 & 0 & $3 \%$ & $0 \%$ & $0 \%$ & $0 \%$ \\
\hline 47 & $S[$ Liv-A-a-60-5\%] & 45.17 & 35 & 0 & $3 \%$ & $0 \%$ & $0 \%$ & $0 \%$ \\
\hline
\end{tabular}

Source: Authors, 2012.

TABLE 4: All annuity strategies ranked by average rank for a male retiree aged 65

\begin{tabular}{|c|c|c|c|c|c|c|c|c|}
\hline \multicolumn{5}{|c|}{ Retirement age 65} & \multicolumn{4}{|c|}{$\%$ years above percentile } \\
\hline $\begin{array}{l}\text { Overall } \\
\text { rank }\end{array}$ & Option & $\begin{array}{c}\text { Average } \\
\text { rank }\end{array}$ & $\begin{array}{l}\text { Best } \\
\text { rank }\end{array}$ & NOV & $20 \%$ & $40 \%$ & $60 \%$ & $80 \%$ \\
\hline 1 & Liv-C-a-65 & 2.67 & 1 & 8 & $100 \%$ & $100 \%$ & $100 \%$ & $100 \%$ \\
\hline 2 & Liv-C-b-65 & 2.70 & 1 & 11 & $100 \%$ & $100 \%$ & $100 \%$ & $97 \%$ \\
\hline 3 & Liv-C-c-65 & 2.93 & 1 & 7 & $100 \%$ & $100 \%$ & $100 \%$ & $100 \%$ \\
\hline 4 & Liv-B-c-65 & 5.23 & 2 & 0 & $100 \%$ & $100 \%$ & $100 \%$ & $97 \%$ \\
\hline 5 & Liv-B-b-65 & 6.30 & 1 & 2 & $100 \%$ & $100 \%$ & $100 \%$ & $83 \%$ \\
\hline 6 & Liv-B-a-65 & 6.73 & 3 & 0 & $100 \%$ & $100 \%$ & $100 \%$ & $80 \%$ \\
\hline 7 & $C[$ Liv-C-b-65-0\%] & 9.90 & 4 & 0 & $100 \%$ & $100 \%$ & $93 \%$ & $60 \%$ \\
\hline 8 & $C[$ Liv- $-a-65-0 \%]$ & 9.97 & 4 & 0 & $100 \%$ & $100 \%$ & $90 \%$ & $67 \%$ \\
\hline 9 & $C[$ Liv-C-c-65-0\%] & 10.90 & 5 & 0 & $100 \%$ & $100 \%$ & $87 \%$ & $53 \%$ \\
\hline 10 & Liv-A-c-65 & 11.00 & 3 & 0 & $100 \%$ & $100 \%$ & $90 \%$ & $53 \%$ \\
\hline
\end{tabular}




\begin{tabular}{|c|c|c|c|c|c|c|c|c|}
\hline \multicolumn{5}{|c|}{ Retirement age 65} & \multicolumn{4}{|c|}{$\%$ years above percentile } \\
\hline $\begin{array}{l}\text { Overall } \\
\text { rank }\end{array}$ & Option & $\begin{array}{c}\text { Average } \\
\text { rank }\end{array}$ & $\begin{array}{l}\text { Best } \\
\text { rank }\end{array}$ & NOV & $20 \%$ & $40 \%$ & $60 \%$ & $80 \%$ \\
\hline 11 & $C[$ Liv-C-b-65-5\%] & 13.53 & 7 & 0 & $100 \%$ & $100 \%$ & $90 \%$ & $7 \%$ \\
\hline 12 & $C[$ Liv-C-a-65-5\%] & 13.77 & 8 & 0 & $100 \%$ & $100 \%$ & $87 \%$ & $13 \%$ \\
\hline 13 & $C[$ Liv-C-c-65-5\%] & 14.40 & 8 & 0 & $100 \%$ & $100 \%$ & $87 \%$ & $7 \%$ \\
\hline 14 & C[Liv-B-c-65-0\%] & 16.60 & 6 & 0 & $100 \%$ & $100 \%$ & $50 \%$ & $10 \%$ \\
\hline 15 & $C[$ Liv-B-b-65-0\%] & 16.93 & 10 & 0 & $100 \%$ & $100 \%$ & $73 \%$ & $0 \%$ \\
\hline 16 & $C[$ Liv-B-a-65-0\%] & 18.00 & 13 & 0 & $100 \%$ & $100 \%$ & $57 \%$ & $0 \%$ \\
\hline 17 & Liv-A-b-65 & 19.10 & 1 & 2 & $100 \%$ & $80 \%$ & $40 \%$ & $20 \%$ \\
\hline 18 & $S[$ Liv-C-c-65-0\%] & 20.10 & 5 & 0 & $100 \%$ & $83 \%$ & $43 \%$ & $7 \%$ \\
\hline 19 & $C[$ Liv-B-c-65-5\%] & 20.70 & 9 & 0 & $100 \%$ & $100 \%$ & $27 \%$ & $3 \%$ \\
\hline 20 & $C[$ Liv-B-b-65-5\%] & 21.30 & 11 & 0 & $100 \%$ & $97 \%$ & $20 \%$ & $0 \%$ \\
\hline 21 & $C[$ Liv-B-a-65-5\%] & 22.47 & 16 & 0 & $100 \%$ & $93 \%$ & $17 \%$ & $0 \%$ \\
\hline 22 & $C[$ Liv-A-c-65-0\%] & 22.67 & 7 & 0 & $100 \%$ & $80 \%$ & $37 \%$ & $7 \%$ \\
\hline 23 & Liv-A-a-65 & 23.07 & 2 & 0 & $93 \%$ & $67 \%$ & $30 \%$ & $20 \%$ \\
\hline 24 & $S[$ Liv-C-a-65-0\%] & 23.57 & 4 & 0 & $87 \%$ & $67 \%$ & $40 \%$ & $10 \%$ \\
\hline 25 & $\mathrm{~S}[$ Liv-C-b-65-0\%] & 24.53 & 7 & 0 & $87 \%$ & $63 \%$ & $33 \%$ & $3 \%$ \\
\hline 26 & $S[$ Liv-C-c-65-5\%] & 25.37 & 14 & 0 & $93 \%$ & $60 \%$ & $27 \%$ & $0 \%$ \\
\hline 27 & $C[$ Liv-A-b-65-0\%] & 25.93 & 10 & 0 & $97 \%$ & $63 \%$ & $13 \%$ & $0 \%$ \\
\hline 28 & $C[$ Liv-A-c-65-5\%] & 26.60 & 11 & 0 & $100 \%$ & $53 \%$ & $10 \%$ & $0 \%$ \\
\hline 29 & $C[$ Liv-A-a-65-0\%] & 28.50 & 11 & 0 & $100 \%$ & $47 \%$ & $7 \%$ & $0 \%$ \\
\hline 30 & $S[$ Liv-C-a-65-5\%] & 29.37 & 6 & 0 & $73 \%$ & $43 \%$ & $23 \%$ & $3 \%$ \\
\hline 31 & $S[$ Liv-B-c-65-0\%] & 29.50 & 22 & 0 & $93 \%$ & $37 \%$ & $0 \%$ & $0 \%$ \\
\hline 32 & $S[$ Liv-C-b-65-5\%] & 29.90 & 15 & 0 & $77 \%$ & $50 \%$ & $10 \%$ & $0 \%$ \\
\hline 33 & $C[$ Liv-A-b-65-5\%] & 30.63 & 10 & 0 & $77 \%$ & $33 \%$ & $13 \%$ & $0 \%$ \\
\hline 34 & $S[$ Liv-B-c-65-5\%] & 33.00 & 25 & 0 & $90 \%$ & $13 \%$ & $0 \%$ & $0 \%$ \\
\hline 35 & $C[$ Liv-A-a-65-5\%] & 33.20 & 12 & 0 & $63 \%$ & $27 \%$ & $7 \%$ & $0 \%$ \\
\hline 36 & Lif-0\%-65 & 34.33 & 19 & 0 & $63 \%$ & $20 \%$ & $0 \%$ & $0 \%$ \\
\hline 37 & $S[$ Liv-B-b-65-0\%] & 34.34 & 27 & 0 & $73 \%$ & $7 \%$ & $0 \%$ & $0 \%$ \\
\hline 38 & $S[$ Liv-B-a-65-0\%] & 36.17 & 19 & 0 & $60 \%$ & $7 \%$ & $0 \%$ & $0 \%$ \\
\hline 39 & $\mathrm{~S}[$ Liv-A-c-65-0\%] & 37.33 & 30 & 0 & $47 \%$ & $0 \%$ & $0 \%$ & $0 \%$ \\
\hline 40 & $S[$ Liv-B-b-65-5\%] & 38.10 & 29 & 0 & $50 \%$ & $0 \%$ & $0 \%$ & $0 \%$ \\
\hline 41 & $S[$ Liv-A-c-65-5\%] & 40.13 & 34 & 0 & $23 \%$ & $0 \%$ & $0 \%$ & $0 \%$ \\
\hline 42 & $S[$ Liv-B-a-65-5\%] & 40.17 & 28 & 0 & $20 \%$ & $7 \%$ & $0 \%$ & $0 \%$ \\
\hline
\end{tabular}




\begin{tabular}{ccccccccc}
\hline \multicolumn{4}{c}{ Retirement age 65 } & \multicolumn{5}{c}{ \% years above percentile } \\
$\begin{array}{c}\text { Overall } \\
\text { rank }\end{array}$ & Option & $\begin{array}{c}\text { Average } \\
\text { rank }\end{array}$ & $\begin{array}{c}\text { Best } \\
\text { rank }\end{array}$ & NOV & $20 \%$ & $40 \%$ & $60 \%$ & $80 \%$ \\
\hline 43 & Lif-5\%-65 & 41.23 & 28 & 0 & $17 \%$ & $3 \%$ & $0 \%$ & $0 \%$ \\
44 & S[Liv-A-b-65-0\%] & 41.37 & 37 & 0 & $10 \%$ & $0 \%$ & $0 \%$ & $0 \%$ \\
45 & S[Liv-A-a-65-0\%] & 43.70 & 33 & 0 & $7 \%$ & $0 \%$ & $0 \%$ & $0 \%$ \\
46 & S[Liv-A-b-65-5\%] & 43.90 & 40 & 0 & $0 \%$ & $0 \%$ & $0 \%$ & $0 \%$ \\
47 & S[Liv-A-a-65-5\%] & 46.17 & 42 & 0 & $0 \%$ & $0 \%$ & $0 \%$ & $0 \%$ \\
\hline
\end{tabular}

Source: Authors, 2012.

\subsection{Average rank}

Average rank for all annuity strategies was calculated by firstly ranking the strategies' present values for each year (from 1960 to 1989) from one (the best) to 47 (the worst). The average rank for each strategy was calculated by adding the rankings for each year and by then dividing the total by 30 (number of years from 1960 to 1989).

The average rank for 47 annuity strategies is also schematically illustrated for a male aged 55,60 and 65 respectively, in FIGURE 1 to FIGURE 3.

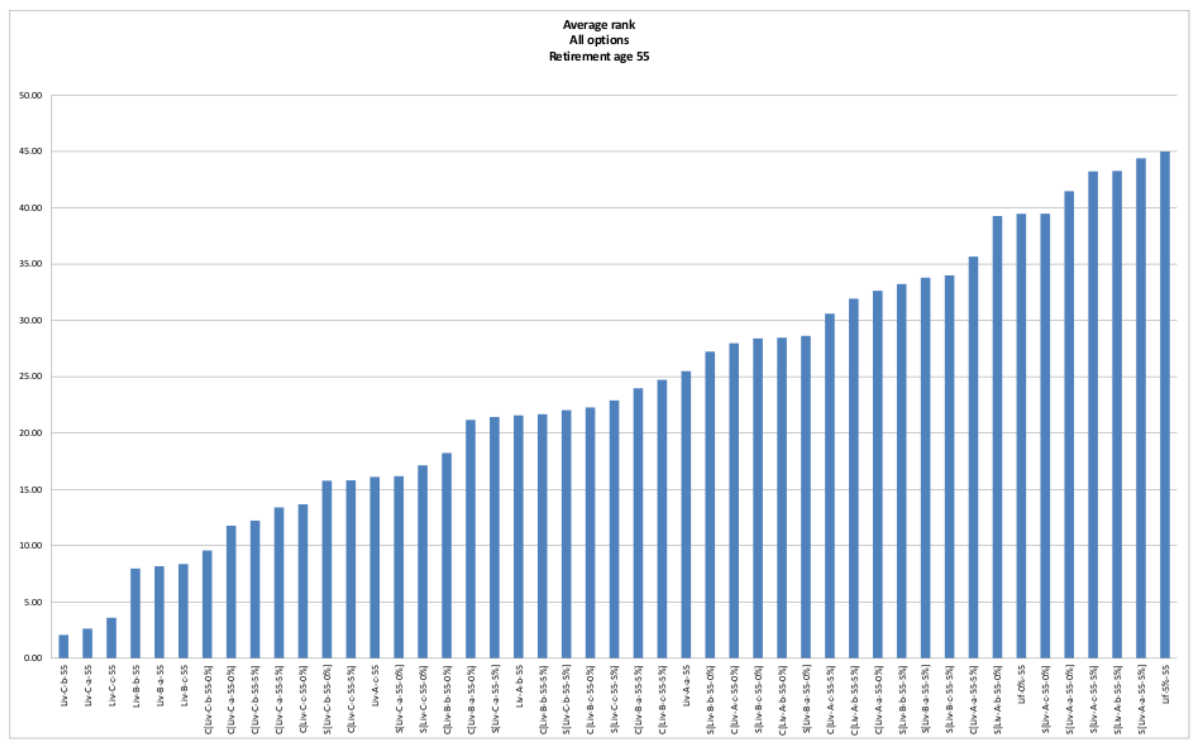

FIGURE 1: Average rank for all annuity strategies for a male retiree aged 55

Source: Authors, 2012 


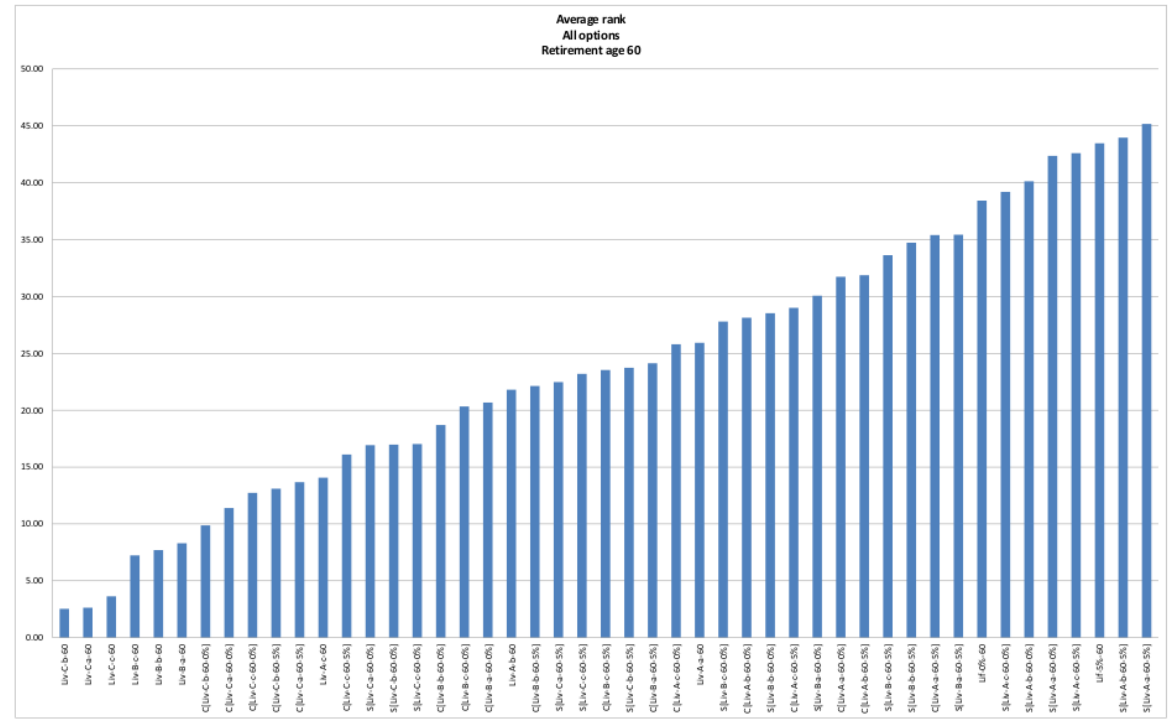

FIGURE 2: Average rank for all annuity strategies for a male retiree aged 60

Source: Authors, 2012

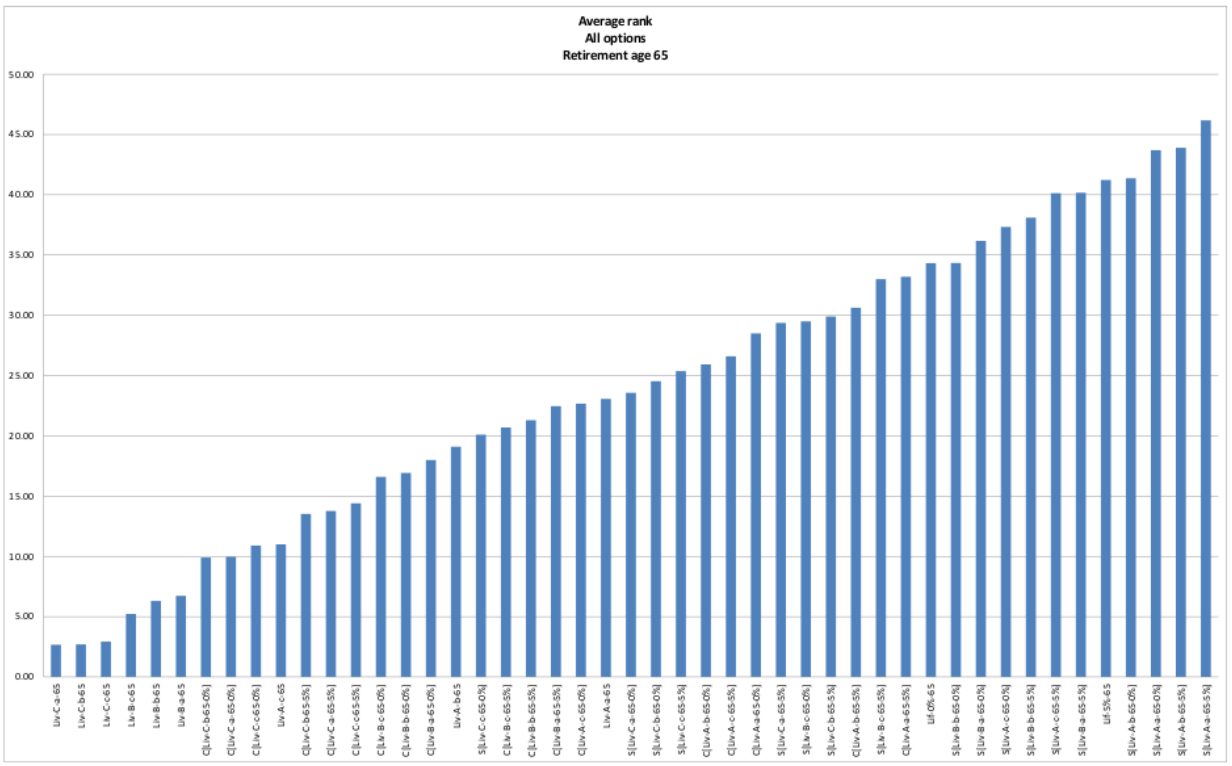

FIGURE 3: Average rank for all annuity strategies for a male retiree aged 65

Source: Authors, 2012

According to this $\mathrm{KPI}$, it is evident that for all retirement ages, living annuity strategies generally outperform composite annuity strategies, which in turn generally outperform switching 
annuity strategies, with life annuity strategies as the worst performer.

\subsection{Best rank and number of victories (NOV)}

Best rank refers to the best rank awarded to each of the 47 annuity strategies over 30 years, from 1960 to 1989 . NOV refers to the number of times a strategy was the best strategy for a single year.

From TABLE 2 it is evident that Liv-C-b-55 performed best 12 out of 30 years and Liv-C-a-55 performed best 10 out of 30 years. Similarly, TABLE 3 shows that Liv-C-b-60 achieved first place 14 out of 30 times, whereas Liv- $C-a-60$ achieved first place 12 out of 30 times. Surprisingly, although TABLE 4 shows that Liv-C-b-65 has a poorer average rank than Liv- $C$ - $a-65$, the former, according to the NOV KPI, was awarded first place 11 out of 30 times, whereas the latter was awarded first place 8 out of 30 times. This implies that for the remainder of the 19 years, Liv-Cb- 65 markedly underperformed relative to the other 46 strategies. It is interesting to note that living annuity strategies were the only strategies over the 30 years that achieved any victories. There were no victories for any composite, switching or life annuity strategies.

\subsection{Percentiles}

For each year (from 1960 to 1989) the $20^{\text {th }}, 40^{\text {th }}, 60^{\text {th }}$ and $80^{\text {th }}$ percentile of the present values for 47 annuity strategies were calculated.

After these percentiles had been calculated, the number of years for which each strategy's present value was above each of these percentiles was added. Subsequently the percentage of time each strategy was above the $20^{\text {th }}, 40^{\text {th }}, 60^{\text {th }}$ and $80^{\text {th }}$ percentile was calculated.

According to this KPI for retirement age group 55, TABLE 2 shows that living annuity strategies with the maximum equity exposure outperformed $80 \%$ of the other strategies at least $97 \%$ of the time.

The worst-performing living annuity strategy (Liv-A-a-55) still managed to outperform $80 \%$ of the other strategies $27 \%$ of the time.

For retirement age group 60 , TABLE 3 shows that living annuity strategies with the maximum equity exposure outperformed $80 \%$ of the other strategies at least $97 \%$ of the time. The worst-performing living annuity strategy (Liv-A-a-60) still managed to outperform $80 \%$ of the other strategies $23 \%$ of the time.

For retirement age group 65, TABLE 4 shows that living annuity strategies with an aggressive or moderate risk profile outperformed $80 \%$ of the other strategies at least $80 \%$ of the time. The worst-performing living annuity strategy (Liv-A-a-65) still managed to outperform $80 \%$ of the other strategies $20 \%$ of the time.

\subsection{Overall rank}

Using average rank as the determining KPI, FIGURES 1 to 3 show that the overall best performers for the three retirement ages were as follows:

- Age 55: Liv-C-b-55 
- Age 60: Liv-C-b-60

- Age 65: Liv-C-a-65

The overall worst performers for the three retirement ages were as follows:

- Age 55: Lif-5\%-55

- Age 60: S[Liv-A-a-60-5\%]

- Age 65: S[Liv-A-a-65-5\%]

Interestingly, the highest present value attained for a single year out of 4230 combinations tested, was for a male aged 55, retiring on 1 January 1977 and investing in a living annuity strategy with an aggressive asset allocation, and withdrawing annually an amount that increases the Rand amount of income by $5 \%$ per annum. The main reason for this feature is the fact that the equity market was at a very low level in 1976/77 and increased significantly for a sustained period in subsequent years.

It is important to note that in all of the annuity options which included full or partial living annuity strategies (pure living, switching and composite annuity strategies), capital was never depleted during the retiree's lifetime. This is mainly due to the maximum restriction of $17.5 \%$ of fund value set on the annual drawdown percentage.

\section{CONCLUSIONS AND LIMITATIONS}

\subsection{Conclusions}

It is evident from the results in section 4 that living annuity strategies are superior to composite annuity strategies, which in turn outperform switching annuity strategies. A retiree would have been worst off had he invested all of his money in life annuities.

The above conclusion seems to be in contrast to international consensus, which is that retirees should invest, from a risk-return perspective, at least a portion of their portfolio in life annuities (Dus et al., 2005). It was also suggested by Dus et al. (2005) that retirees with a low risk aversion should opt to either defer annuitisation until a later age, or should consider an initial blending strategy where life annuities are combined with a phased withdrawal plan.

The above conclusion also seems to be in contrast with the findings of the two recent South African studies.

In the study by Goemans and Ncube (2008), the authors came to the conclusion that retirees will only be able to obtain a level of income from a living annuity comparable to that of a life annuity if they are willing to tolerate the disadvantage of a decreasing income stream.

In the study by Lodhia and Swanepoel (2012), the authors put forward that a life annuity is better equipped than a living annuity to provide a real income for life.

\subsection{Limitations of the study}

In contrast to the study conducted by Goemans and Ncube (2008), where risk is defined as the probability of a cash flow not meeting a certain minimum benchmark, no explicit risk 
measure was used in this study, where the approach was followed that cash flows not meeting a certain minimum level, as in the case of a life annuity benchmark, will be reflected in the present values of the various annuity strategies. However, one could, for example, incorporate an indicator measuring the number of times a cash flow payment did not meet a certain benchmark level, after which the size of such shortfall could then be determined.

It should be noted that, for comparative purposes, living annuities were constructed as if they had existed since 1960. Furthermore, with-profit as well as inflation-linked annuities were excluded from the study, due to their short history and relative lack of popularity.

In order to compare different annuity strategies, the present values of the monthly cash flows provided by these strategies were calculated. In using this method, the present values are very sensitive with respect to the chosen discount rate. Hence, it could be worthwhile to pursue alternative discount rates, for example ruling long-term rates, to discount monthly cash flows.

\section{LIST OF REFERENCES}

Babbel, D.F. \& Merrill, C.B. (2006). Rational decumulation. Wharton Financial Institutions Center. (Working Paper No. 2006, pp. 6-14).

Botha, M., Rossini, L., Geach, W., Goodall, B. \& Du Preez, L. (2011). The South African Financial Planning Handbook 2012. Durban: LexisNexis.

Brown, J.R., Mitchell, 0.S. \& Poterba, J.M. (2001). The role of real annuities and indexed bonds in an individual accounts retirement program. Risk aspects of Investment-based Socia/ Security Reform, Chicago: University of Chicago Press.

Dus, I., Maurer, R. \& Mitchell 0.S. (2005). Betting on death and capital markets in retirement: a shortfall risk analysis of life annuities versus phased withdrawal plans. Financia/ Services Review, 14, pp. 169-196.

Firer, C. \& McLeod, H. (1999). Equities, bonds, cash and inflation: Historical performance in South Africa 1925 to 1998. Investment Analyst Journal, 50(1), pp. 7-28.

FTSE/JSE. (2008). Africa Index Series, A comprehensive guide. [Online] Available: http://www.jse.co.za/Libraries/FTSE-JSE - Education - Comprehensive (Accessed 24 August 2012)

Gerrard, R., Haberman, S. \& Vigna, દ. (2004). Optimal investment choices post-retirement in a defined contribution ension scheme. Insurance: Mathematics and Economics, 35(2), pp. 321-342.

Goemans, M. \& Ncube, M. (2008). Optimal Annuity Strategies after Retirement. Presented at the South African Actuarial Convention, 0ctober 2008.

Horneff, W.J., Maurer, R., Mitchell, 0.S. \& Dus, I. (2008). Following the rules: Integrating asset allocation and annuitization in retirement portfolios. Insurance: Mathematics and Economics, 42, pp. 396-408.

Johannesburg Stock Exchange (JSE). (2000). BEASSA Total Return Indices. [Online] Available: http://www.jse.co.za/Libraries/BESA related documents/BEASSA total return indices 2000. sflb.ashx (Accessed 24 August 2012). 
Johannesburg Stock Exchange (JSE). (2010). ASSA Fixed Income Indices. [Online] Available:

http://www.jse.co.za/Libraries/BESA Indices overview/Tribook.sflb.ashx (Accessed 24 August 2012).

Kapur, S. \& Orszag, J.M. (1999). A portfolio approach to investment and annuitization during retirement. London: University of London.

Life Offices Association of South Africa (LOA). (2008). Code on Living Annuities. Circular No: 82/2008. [Online] Available: http://www.docstoc.com/docs/18565164/LOA-CIRCULAR-22nd-FLOOR-ABSACENTRE-2- RIEBEEK-STREET-P-0-BOX-5023 (Accessed 14 November 2012).

Lodhia, M. \& Swanepoel, J. (2012). Living versus guaranteed annuities: In search of a sustainable retirement income. Presented at the South African Actuarial Convention, October 2012.

Statistics South Africa (StatsSA). (2009). Consumer Price Index, key changes in 2009. [Online] Available: http://www.statssa.gov.za/cpi/documents/CPI\%20booklet $\% 20-\% 20$ final $\% 2016 \% 20$ Oct\%2008.pdf (Accessed 24 August 2012). 